\title{
Party system change at work: the 2014 legislative election in Bulgaria
}

\author{
Ekaterina R. Rashkova ${ }^{1, *}$ \\ 1 Institute of Political Science, University of Innsbruck, Innsbruck, Austria \\ * E-Mail: ekaterina.rashkova@uibk.ac.at
}

\begin{abstract}
This discussion of the Bulgarian national election offers a short analysis of the electoral competition in Bulgaria. As a new democracy, Bulgaria is facing many political challenges, including the inability to provide a stable political environment, which will ensure its further economic development and future within the EU. Still battling between the strong grip of Russia and the country's attempt to take on a new path, the 2014 election, produced a very fragmented parliament. Yet, this electoral note argues that this development might signify that Bulgaria is finally parting with its strong former communist party, the BSP, and despite the current political turbulence, the break-up of the BSP may lead to stronger and more pro-Western government in the future.
\end{abstract}

\section{Keywords:}

Electoral politics, Bulgaria election 2OI4, party system development

\section{Parteiensystem im Wandel: Die Nationalratswahlen 2014 in Bulgarien}

\section{Zusammenfassung}

Als relativ neue Demokratie sieht sich Bulgarien einer Reihe Herausforderungen gegenüber; dazu gehört etwa die Schwierigkeit politisch stabile Bedingungen für die weitere ökonomische Entwicklung des Landes sowie seine Rolle in der Europäischen Union herzustellen. Nach wie vor übt Rußland großen Einfluß auf Bulgarien aus; gleichzeitig gibt es verstärkte Ambitionen das Land mehr nach Westen zu orientieren. Als Konsequenz ergaben die Wahlen in 2014 ein parteipolitisch äußerst fragmentiertes Parlament. Dennoch argumentiert dieser Beitrag, dass dieses Ergebnis das Ende der dominanten Rolle der ehemals kommunistischen Partei (jetzt BSP) bedeuten könnte; trotz politischer Turbulenzen in der Gegenwart könnte daraus eine stärkere und mehr nach Westen orientierte Regierung resultieren.

Schlüsselwörter:

Wahlpolitik, Wahlen in Bulgarien 20I4, Entwicklung des Parteiensystems

The author has declared that no competing interests exist. 


\section{Introduction}

After more than 15 months of demonstrations, which resulted in the resignation of the Oresharski cabinet on October 5th, 20I4, Bulgarian citizens had another chance to change the status quo. Many saw the election as an opportunity to elect a legislature and cabinet that would reduce poverty, enforce the rule of law, and bring about a democratic future promised by many of the politicians of the transition period. The resulting vote distribution signaled for even further fragmentation of the parliament, as not four, as in 2013, but eight political parties passed the necessary threshold. This outcome can be deemed just as bad, as good. On the one hand, further fragmentation is detrimental to the ability to form a stable government, on the other however, the fragmentation is a result of the breaking-up of the Left. While there has been a splinter from the Bulgarian Socialist Party (BSP) in 1997, the Euroleft, the latter never became a viable player in Bulgaria's political life, something, which the current fragmentation of the Left, could potentially do.

These results are interesting empirically as they offer a natural experiment of party system re-alignment, valuable to those studying party system development in the region. Perhaps even more important is the theoretical insight which the outcome suggests, i.e. that the impetus for party system change was interparty conflict, rather than the institutional incentives often cited by comparativists (Benoit 200I; Innes 200I, Tavits 2005, 2008; Rashkova 20I3a). In the case of Bulgaria's latest election, intra-party conflict contributed to the demise of the Bulgarian Socialist Party and to the entry of at least two new formations in parliament.

\section{Background}

The early parliamentary election in Bulgaria needs to be seen in light of the events that took place in the country since the inauguration of the previous government (May 20I3). Having come to power in a legitimate, yet controversial manner, the Bulgarian Socialist Party formed a minority coalition with the Movements for Rights and Freedom (MRF), the party largely representing the interests of the ethnic Turkish minority in Bulgaria. The two parties enjoyed I2O out of a 240-seat parliament, counting on support from the nationalist party ATAKA. ATAKA's support was necessary not only for the passage of legislation, but for the collection of the required quorum of MPs for the operation of the parliament. Thus, the two smallest parties in the 2013 parliament (MRF and ATAKA) became key veto players. The government was headed by Plamen Oresharski, a politician from the Bulgarian Socialist Party, who previously served as Minister of Finance in the triple coalition government of Sergei Stanishev (2005-2009).
In light of the fact that the true winner of the election ${ }^{\mathrm{r}}$, the political party of former PM Boyko Borissov, ${ }^{2}$ GERB (abbreviated from the Bulgarian version of Citizens for European Development of Bulgaria), was in opposition, the political scenario forming in Bulgaria was very different from what the popular vote had called for. In this political climate, the appointment of Head of the National Security Agency of a media magnate, with infamous reputation of connections to the underground world, triggered massive protests demanding the resignation of the newly formed cabinet. Public demonstrations continued with high intensity for over 6 months, still the Oresharski cabinet remained in office until July 2014. The reason for the cabinet resignation was not the enduring mass protests, but a media war involving two of the largest business owners (and politically involved figures) in Bulgaria and the bankruptcy of one of Bulgaria's major banks which caused serious inter-party conflicts within the Bulgarian Socialist Party and its leadership.

\section{Rules of the game and the new electoral law}

The parliament in Bulgaria is elected by popular vote for a four-year term with a proportional representation system. The electoral rules have been amended multiple times in the recent years and the newest Electoral Law was promulgated on March 5, 20I4. ${ }^{3}$ According to this law, voters are granted preferential voting in addition to the vote they cast for their favored political party (Art. 246.2). The introduction of the preference is a result of popular demands for more accountability, although some have argued that the preference is virtually ineffective given the high threshold of $7 \%$ that candidates need to collect in order to move up the party list (Dnevnik, 20I4). Originally, many the people, as well as some of the political elite wanted the Bulgarian electoral system to be changed to a single-member plurality system, and in this way produce more transparency and account-

I GERB had received the highest amount of votes in the 2013 election, but still nearly 20 percent short of being able to form a government. Given that none of the other right-wing formations, such as the Blue Coalition, made it past the electoral threshold, GERB did not want to use its government formation mandate because it did not see it possible to coalesce with any of the other elected parties (namely, the BSP, MRF and ATAKA).

2 Boyko Borissov voluntarily stepped down from power 3 months before the end of his party's term, as a response to the beginnings of social unrest and people's demonstrations against high energy prices, high level of political corruption, and the lack of law and order (for more details on this or the ensuing political events in Bulgaria, see Rashkova 20I3b and 2014).

3 The Electoral Code can be found here (in Bulgarian): http://dv. parliament.bg/DVWeb/showMaterialDV.jsp?idMat=82965 (last accessed: 20.I.20I6). 
ability in the link between society and politicians. The new electoral law also lowers the barrier to entry - political parties and coalitions wishing to compete had to pay 2500 Bulgarian Lev (BGN; roughly $€$ I.250). The deposit for initiative committees was set to IOo BGN (Art.I29.2). Previously, the pre-electoral deposit was I0.00o BGN and higher in preceding years. The deposit is reimbursed to all those who secure at least $\mathrm{I} \%$ of the popular vote (Art. 130).

Financing the electoral campaign, and especially the ability to reach voters through the media, was another point of contention within the elite and between the elite and the protesting public. Partially addressing the popular demand for rules which would allow a change in the players of the political game, the new law introduces the so-called "media packages". Worth 40.00o BGN, these funds are available to any political party wishing to contest elections but does not already have public subsidy. The latter is given to all political parties which have secured at least I\% of the popular vote and is paid on the basis of a fixed sum per vote received. Finally, in an attempt to battle corruption and the potential influence of economic interests in the political process, the new law obliges all donations exceeding the minimum monthly salary to be accompanied by a document certifying the origin of the funds (Art. I69. I) and stipulates that donations larger than I.OOo BGN can only be made via bank transfer (Art. I70.I).

\section{What was at stake? The electoral campaign}

Unlike typical electoral campaigns where debate and policy proposals are at the heart of the campaign, the preparation for the early legislative election in Bulgaria can more accurately be classified as a "non-campaign". This is largely a result of the fact that the election was anticipated for over a year when the demonstrations requesting the resignation of the outgoing government began. The months during which the Oresharski cabinet was in power, were spent as an electoral campaign by all those whowanted the cabinet resignation. Consequently, at the commencement of the official electoral campaign period, both elite and voters "knew" where various competitors stand and what the election of one party versus another would bring. The major question of contention was Bulgaria's political future, especially its long-term energy strategy. Similar to being back at the threshold of democratization, the question of whether the country intends to go with the East or the West seemed to be put back on the table. Taking the country on a firm pro-European path, and converging with the European Union on many issues, including energy, was the first out of ten priorities of the leading right political party, GERB. Its campaign program listed "ensuring the functioning of the state by stabilizing the institutions and returning the European direction of the country's path" (GERB, 2OI4) as the party's top goal. GERB's platform also promised economic growth, key infrastructure developments, and exchanging the 'shadiness' of the politics of the previous cabinet with transparency.

The fact that the direction of Bulgaria's political path was the major issue of the campaign is a result of, amongst others, the controversial developments around the South Stream pipeline, a major investor in which has been Russia. The Oresharski cabinet changed some of the details in the legal rules binding its construction, which would allow "going around" EU regulations - an action, which not only cemented Russia's grip on Bulgaria's energy sector, but gave grounds to the European Commission to start an investigation against Bulgaria.

$\mathrm{BSP}$, who according to media reports entered the race as the "biggest loser" from the previous government (the party's vote dropped from 26.6 percent in 2013 to the mere I5.4 in 2014), counted on its traditional messages of increasing incomes and decreasing unemployment. The new coalition from rightist parties, Reformatorski Bloc, emphasized law and order, as well as a definite turn away from anything connected to Russia and the East. Bulgaria without Censorship, the newly formed nationalist party, campaigned primarily on nationalistic slogans, promising also an increase in employment opportunities. Patriotic Front, a coalition between several political parties (one of which a splinter from the nationalist party ATAKA) campaigning on national values. Finally, the MRF carried out a campaign of "understanding", emphasizing the importance of a future understanding between the parliamentary represented political parties, so that there would be a stable cabinet, which will ensure the working of the country's institutions.

\section{Results}

Amidst the electoral campaign slogans, the true battle in the 2014 election in Bulgaria was about whether the country will be once again ruled by the Left and continue tying the knot on the relationship with Russia, or whether it will be governed by the Right, which would have the difficult task of undoing the course of action for several key for the country's future projects, as well as re-altering the organization of various institutions to increase accountability and secure the separation of powers.

The results of the vote on 5 October 2014, however, did not give a clear answer. With the relatively low voter turnout of 48.66 per cent, the outcome of the election gave rise to a highly fragmented parliament consisting of eight political parties. The results of the election are presented in Table I. The winner of the election was 
Table 1: Results from the 2014 legislative election in Bulgaria

\begin{tabular}{|c|c|c|c|c|}
\hline \multirow{2}{*}{ Political Party } & \multicolumn{2}{|c|}{2013} & \multicolumn{2}{|c|}{2014} \\
\hline & Votes (\%) & Seats & Votes (\%) & Seats \\
\hline GERB & $1081605(30.54)$ & 97 & $1072491(32.67)$ & 84 \\
\hline BSP & $942541(26.61)$ & 84 & $505527(15.4)$ & 39 \\
\hline MRF & 400466 (11.31) & 36 & $487134(14.84)$ & 38 \\
\hline Reformatorski Bloc & -- & -- & $291806(8.89)$ & 23 \\
\hline Patriotic Front & -- & -- & $239101(7.28)$ & 19 \\
\hline Bulgaria w/o censorship & -- & -- & $186938(5.69)$ & 15 \\
\hline ATAKA & $258481(7.3)$ & 23 & $148262(4.52)$ & 11 \\
\hline ABV & -- & -- & $136223(4.15)$ & 11 \\
\hline Invalid votes & 90047 & & 218125 & \\
\hline Total votes / seats & 3632174 & 240 & 3501269 & 240 \\
\hline
\end{tabular}

Note: The results include only parliamentary parties. Data comes from the Central Electoral Commission (www.cik.bg).

former PM Borissov's party GERB, which received 32.67 per cent of the vote. But even with more than twice as many seats as its largest competitor, the BSP, GERB was still short of nearly I8 per cent to secure a stable government. As a result, it held consultations with all represented political parties to find an option for building a working coalition. After two rounds of consultations, the party formed a broad right-wing minority cabinet officially partnering with Reformatorski Bloc, but also relying on support from the Patriotic Front and ABV, the newly formed splinter party by former President and BSP leader, Georgi Purvanov, in order to achieve the necessary parliamentary majority. One of the key negotiating barters was the appointment of Ivailo Kalfin, a key ABV politician, ${ }^{4}$ as deputy Prime Minister and Minister of Labour.

\section{Conclusion}

The early legislative election in Bulgaria resulted in an eight political party parliament. A broad minority coalition government was formed between GERB and Reformatoski Bloc, but with the parliamentary support of two additional political formations. The precedent of the 2014 election however, was not the biggest winner, but the biggest loser - the BSP. Having largely de-legitimized itself during the Oresharski cabinet, and alien-

$4 \mathrm{ABV}$ is a newly formed political party led by former president of the Republic and key former leader of the Bulgarian Socialist Party, Georgi Purvanov. Thus, the ABV, while still supporting many socialist values, is in clear opposition with the previously ruling troika - BSP, DSP, and ATAKA. ated many of its supporters (as a result of intra-party battles over the party's leadership and its aim to keep close ties with Moscow), as well as some of its previous key political elite figures, the Bulgarian Socialist Party lost this election. The party which had been one of the two main contenders for the entire post-communist period of the country until then, was being marginalized to the mere 15 per cent of the popular vote, and was on the verge of losing the second place to the MRF, whose performance was only 0.2 per cent lower. BSP's loss was not only a clear message that the party future is at stake as a result of its unresolved internal conflicts, but also a strong signal for the re-arrangement of the party system. For the first time since the change of the regime the Left is not united, but divided. For the first time since its new democratic history, Bulgaria has an actual chance of re-organizing the left political spectrum in such a way that it not only ceases to have one party which monopolizes the vote of all those left of center, but also gives a chance for the building of a real social democratic political party in the future. 


\section{References}

Benoit, Kenneth (200I). District magnitude, electoral formula, and the number of parties, in: European Journal of Political Research, Vol. 39(2), 203-224.

Dnevnik (2014). Новият Изборен кодекс: открийте разликите (The New Electoral Code: Find the Differences), published in Dnevnik Daily published on 25 February. Internet: http://www.dnevnik.bg/bulgaria/2OI4/O2/25/2248904_noviiat_izboren_kodeks _ otkriite_razlikite/(last accessed 24.IO. 20I4).

GERB (20I4). Програма за реформи ПП ГЕРБ (Preelectoral Programme). Internet: http://www.gerb.bg/ $\mathrm{bg} /$ news/index/download/fileId/38723/isMultime$\mathrm{dia} / \mathrm{I}$ (last accessed 24.IO. 2014).

Innes, Abby (200I). Party competition in Post-Communist Europe: the great electoral lottery, Center for European Studies, Central and Eastern Europe, LSE Working Paper Series 54.

Rashkova, Ekaterina R. (2013a). Learning the game: explaining party system convergence in European democracies, in Political Studies, Vol. 62(4): 804-823, DOI: IO.IIII/I467-9248.I2077

Rashkova, Ekaterina R. (2013b). In the midst of political crisis, Bulgarians are searching for accountability and justice from their government, LSE EUROPP Blog. 28.2. Internet: http://bit.ly/YzDDiB (last accessed: 25.I.2016).

Rashkova, Ekaterina R. (2014). With Plamen Oresharski's government on the verge of resigning, it remains to be seen whether Bulgaria can finally emerge from its political crisis, LSE EUROPP Blog, 26.6. Internet: http://bit.ly/ImwABuz (last accessed: 25 I.20I6).

Tavits, Margit (2005). The development of stable party support: electoral dynamics in Post-Communist Europe, in: American Journal of Political Science, Vol. 49(2), 283-298.

Tavits, Margit (2008). On the linkage between electoral volatility and party system instability in Central and Eastern Europe, in: European Journal of Political Research, Vol. 47(5), 537-555.

\section{Author}

Ekaterina R. Rashkova-Gerbrands is Assistant Professor in Comparative Politics at the Institute of Political Science, University of Innsbruck, and currently fellow at the Netherlands Institute of Advanced Studies (NIAS). Her research interests lie in electoral and party systems and the strategic behavior of political actors, institutions, party system development, party regulation and gender representation and has appeared, amongst others, in Comparative European Politics, International Political Science Review, Party Politics and Political Studies. 